\title{
Understanding of sustainable tourism among Russian tourism
}

\section{managers}

\author{
Sergey Kask ${ }^{1 *}$, Tiiu Kull ${ }^{2}$ and Kati Orru ${ }^{3}$
}

Received: 23/02/2016 Accepted: 30/05/2016

\footnotetext{
1 PhD candidate, Estonian University of Life Sciences; email: sergey.kask@gmail.com

2 Professor of The Department of Botany, Estonian University of Life Sciences; email: tiiu.kull@emu.ee

3 Researcher at the Institute of Social Sciences, University of Tartu; email: kati.orru@ut.ee

* Corresponding author
}

\begin{abstract}
An examination of the understanding of sustainable tourism among Russian tourism managers (RTM) offers insights into methods for designing acceptable sustainable tourism development strategies. Documentary analysis of tourism legislation revealed inconsistency in policies at both local and federal levels while five semi-structured interviews with RTMs revealed low levels of awareness of key aspects of sustainable tourism concepts. Delphi consensus search disclosed RTMs' associations of sustainable tourism such as nature travel, green tourism, ecological and outdoor, sports and friendly tourism. Achieving a comprehensive understanding of sustainable tourism by RTMs requires raising their awareness on the subject through training and facilitation in the elaboration of sustainable tourism strategies.
\end{abstract}

(C) 2016 Varna University of Management. All rights reserved

Keywords: sustainable tourism, Russia, tourism managers.

Citation: Kask S., T. Kull and K. Orru (2016) Understanding of sustainable tourism among Russian tourism managers. European Journal of Tourism Research 14, pp. 101-105

\section{Introduction}

The goal of this paper is to shed light on the understanding of sustainable tourism by Russian tourism managers (RTM). The subject is poorly covered in literature, yet worth exploring in order to elaborate initiatives for sustainable tourism development acceptable to RTMs. Sustainable tourism may benefit from collective actions by bringing together stakeholders (local authorities, tourism managers, tourists and local population) to develop mutually agreed initiatives and strategies
(Bramwell, 2011). The role of the state however, previously considered as the sustainable policy initiator, faces serious challenges when considering the performance of such policies (Hall, 2011). One of the reasons Choi \& Murray (2010) suggest, is the reluctance of key state actors to admit their failures when sustainability goals are not reached. Potential for overcoming this issue may exist in broadening the representation of sustainable tourism policy makers, including for example self-organized community groups and 
private enterprises, i.e. tourism practitioners (Choi \& Murray, 2010). Careful consideration of stakeholders' views and attitudes is as critically important for policy design as it is for the effective implementation of sustainable tourism initiatives in the longer term (Brandon et al., 2010).

This paper adopts the concepts for sustainable tourism as defined in the United Nations (Rio+20, 1997) guide for sustainable strategy building. Sustainable tourism is understood to be 'tourism that respects local people and travellers, cultural heritage and the environment'. In order to develop a feasible strategy for sustainable tourism planning it is vital to take into account the following key components: nature preservation (Ballantyne et al., 2009), cultural diversity and social contract (Hall \& Brown, 2006; Rigall-I-Torrent, 2008). Achieving only a low level of mutual agreement among RTMs on nature-based tourism phenomena has been shown (Vespestad, 2010) to result in a failure to form the backbone policy that could help to coordinate consistent sustainable tourism practices (Kuskov, 2006) and indicates a shallow understanding of sustainable tourism requirements by RTMs (Karmalskaya, 2013).

An important point addressed in the literature concerns the problematic implementation of sustainable tourism principles in areas where tourism strategies are designed regionally (e.g. in the Baikal case analysed by Maksakova, 2005). Strategies are difficult to put into effect without proper action guidelines, e.g. when service standards remain underdeveloped (Zeletdinova, 2005). Problems also stem from the poor correlation between the tourism and economic development plans of a region (Maksakova, 2005).

\section{Methodology}

Because of limited knowledge in the field, an exploratory case study design was selected to describe the phenomena from the participants' perspective (Marshall et al., 1999; Yin, 2003b). The current state of sustainable tourism development in Russia was explored through documentary analysis of tourism federal law, two federal programs and five local tourism development strategy documents. Secondly, semi-structured interviews that are commonly applied in exploring social attitudes in a specific set of circumstances (Yin 2003a) were conducted. Russia is a highly centralized economy with headquarters of major tourism operators based in Moscow. Thus, top 20 tourism sales companies from Moscow were approached in December 2012. After a short briefing on the current research objectives with managers involved in business development, five companies confirmed their commitment to participate in the research. Each informant was interviewed during a personal meeting lasting 1 to 2.5 hours at their company office. In order to present RTMs consensus understanding of sustainable tourism a Delphi consensus search (Gokhale, 2001; Linstone \& Turoff, 2011) was employed. Two weeks after the interview sessions the results were tabulated and sent by e-mail to all participants asking for feedback.

\section{Discussion of findings}

The documentary analysis revealed that local and federal legislation only partially cover sustainable tourism principles, such as nature conservation, environmental ethics and social responsibility. Local tourism strategies in three of the five regions that were examined, repeat general provisions of federal tourism policy but lack mechanisms for the implementation of some sustainable tourism principles. For example, in Murmansk region, the tourism development strategy does not comprehensively cover the estimated social impact of incoming tourism growth. Additionally, for the preservation of traditional occupations of local minorities in this area, a more specific approach is required, taking into account declining national minorities. This issue was discussed by Zeletdinova (2005), who pointed out that sustainable tourism practices have previously been described as sporadic and largely unregulated in terms of local cultural background. Maksakova (2005) highlighted that sustainable tourism development in Russia often needs a more consistent and systematic approach.

The ad hoc nature of the sustainable tourism industry in Russia was also supported by our interviews. For example, interviewee (IS) explained: "I am not familiar with any other companies practicing sustainable tourism." 
Table 1. Russian tourism managers' consensus understanding of sustainable tourism

\begin{tabular}{cc} 
Terms & Attributes \\
Nature travel & Cognitive, national parks, wildlife, countryside \\
Green tourism & Cognitive, friendly, nature protection \\
Ecological & Ecotourism \\
Outdoor & Fishing \& hunting \\
Sports & Rafting, alpinism, ecotourism \\
Friendly tourism & Green, togetherness, emotional unity \\
\hline
\end{tabular}

Recent analysis (Kagan, 2013) showed that in practice most Russian sustainable tourism initiatives are realized intuitively and stem from the goodwill of tourism planners rather than from a scientifically supported knowledge base or learning from international tourism practices.

Interviews demonstrated little mutual understanding regarding the attributes of sustainable tourism from the perspective of RTMs. Data from the interviews illustrated that respondents associated a variety of terms with the phenomena of sustainable tourism.

In Table 1, terms that respondents used to refer to sustainable tourism are given along with attributes associated with them. Several types of tourism domain were mentioned, such as nature tourism, green and ecological tourism, outdoor and sports activities, and friendly tourism. Furthermore, nature protection and local cultural heritage preservation were brought out in individual interviews as elements of sustainable tourism. These attributes were mentioned by different informants, but were included in the table only after the consensus round ended in mutual agreement by all informants. As presented in Table 1 the connection between terms and attributes may seem subjective and even doubtful, for example, "friendly tourism" was referred to as togetherness and emotional unity whereas the literature points rather more towards ecologically sound tourism. Earlier analysis by Zeletdinova, (2005) suggested that out-of-date professional education of tourism practitioners hinders further development of sustainable tourism practices in Russia. Low knowledge levels of modern sustainable tourism standards among RTMs is partly driven by a gap between current tourism education in Russia and sustainable tourism concepts developed by the global scientific community (Kokorev, 2010).
Individual interviews demonstrated a rather limited understanding of sustainable tourism among RTMs, which can make elaboration of efficient tourism policies difficult (Castellani et al., 2010).

None of the respondents demonstrated a broad understanding of the sustainable tourism concept as defined by the United Nations (Rio+20, 1997). Their focus was set on types of tourism activities, rather than the application of sustainable principles, nature conservation requirements or local socio-cultural protection issues. However, after the individual interviews were conducted, a later consensus round ended with a set of commonly agreed attributes of sustainable tourism closely resembling the United Nations' definition. This demonstrates that discussion panels may benefit the RTMs understanding of sustainable tourism even though respondents may have a quite fragmented knowledge of the topic. A mutual understanding of real sustainable tourism objectives may provide a solid ground for sustainable tourism planning (Ateljevic, 2010) providing a higher quality of sustainable initiatives. For example, one interviewee (DM) contrasted sharply, sustainability endeavours and tourism activities:

"Sustainability versus tourism. These two things are contradictory. More tourism means less sustainability and vice versa."

As (IS) explained "From my point of view, cultural heritage should be defended along with nature when we talk about sustainable tourism."

Interviews brought out that sustainable or green tourism are means of nature protection from the RTM perspective. Informants often 
equated the meaning of sustainable tourism with environmental purity and ecological balance. The term "green tourism" contains a nature protection element, which is an important component of the sustainable tourism concept (Ballantyne et al., 2009). During the initial interviews, two respondents referred to green tourism as connected with the activities of Greenpeace. For example, one manager (TP) explained green tourism as follows: "Green tourism is something that Greenpeace does."

All respondents referred to a nature-based element as crucial for sustainable tourism, though this is not inevitably a prerequisite according to internationally recognized definitions (Rio+20, 1997). In fact, the term "nature tourism" was commonly used as a synonym for sustainable tourism by RTMs. The following comment from an RTM is an example in this regard: "Sustainable tourism is when tourists visit nature for sightseeing and wildlife [interview with ON]." Importantly, nature-based tourism was not related to sustainable tourism by RTMs (Vespestad, 2010).

RTMs tended to classify sustainable tourism by the types of physical activities involved (e.g. fishing, rafting and wildlife watching). As one interviewee (VS) put it: "Sustainable tourism is for example alpinism or other sport events that may need a good command of training in the fresh air outdoors." The interviewed managers did not distinguish sustainable tourism from outdoor activities. This may indicate that, being generally unfamiliar with sustainable tourism concepts, RTMs still pursue a healthy and nature-based image of it. This could be interesting to verify through further research.

Another common perception of sustainable tourism was its exclusiveness and the untouched nature of the travel destinations. The interviewees demonstrated an understanding that green tours take travellers to places difficult to reach and that have been rarely visited in the past. As one interviewee (IS) explained it: "Sustainable tourism is when people choose unique places for their travel. Such places are located in isolated from wellknown routes." The interviewed RTM understood sustainable tourism as a somewhat rare type of travel, more like an extraordinary experience affordable only by a limited group of people with a higher than average income. This demonstrates how far from reality RTMs perception can reach in contrast, which may become a barrier for the improvement of communication between stakeholders (Bramwell, 2011).

Interestingly, a consensus was reached among RTMs that virtual travel using $3 \mathrm{D}$ visualization could potentially be included in strategies for the sustainable tourism development of areas where carrying capacities have been reached. They also agreed upon the necessity for more intense cooperation between tourism stakeholders in the development of sustainable tourism in Russia and pointed out that training may raise awareness of sustainable tourism. RTMs agreed that public discussion may also positively impact on the improvement of tourism legislation.

\section{Conclusion}

A limitation of the current study is that only 5 from more than 80 Russian regions were observed in the study, whereas RTMs' understanding of sustainable tourism may still significantly differ. The paper highlights the shallowness of RTMs' understanding of sustainable tourism concepts. The attitudes towards sustainable tourism amongst RTMs were largely influenced by their personal background in the industry rather than by internationally adopted concepts. RTMs described sustainable tourism in terms of 'outdoors activities', 'visits to unique places', 'nature-based tourism', 'friendly tourism' and 'green tourism'. This observed lack of understanding of sustainable tourism principles by RTMs is an obstacle to the elaboration of feasible strategies for sustainable tourism development. Greater cooperation between tourism stakeholders and training are required to initiate public discussion and raise awareness of sustainable tourism in Russia. This in turn may facilitate an improvement in tourism legislation.

An interesting and unexpected outcome was that virtual travel, derived from real destinations where carrying capacities are overexploited, was perceived by RTMs as a tool capable of 
benefitting nature conservation. However, further research into the prospect of virtual travel is required. This knowledge could be useful for effective local and international environmental policy planning and implementation.

\section{References}

Ateljevic, J. (2010). Sustainable tourism futures: Perspectives on systems, restructuring and innovations. Tourism Management, 31(4), 559-560.

Ballantyne, R., Packer, J., \& Hughes, K. (2009). Tourists' support for conservation messages and sustainable management practices in wildlife tourism experiences. Tourism Management, 30(5), 658-664.

Bramwell, B. (2011). Governance, the state and sustainable tourism: A political economy approach. Journal of Sustainable Tourism, 19(4-5), 459-477.

Brandon, P. S., \& Lombardi, P. (2010). Evaluating sustainable development in the built environment. New York: John Wiley \& Sons.

Castellani, V., \& Sala, S. (2010). Sustainable performance index for tourism policy development. Tourism Management, 31(6), 871-880.

Choi, H. C., \& Murray, I. (2010). Resident attitudes toward sustainable community tourism. Journal of Sustainable Tourism, 18(4), 575-594.

Gokhale, A. A. (2001). Environmental initiative prioritization with a Delphi approach: A case study. Environmental Management, 28(2), 187-193.

Hall, C. M. (2011). Policy learning and policy failure in sustainable tourism governance: From first-and second-order to third-order change? Journal of Sustainable Tourism, 19(4-5), 649-671.

Hall, D. R., \& Brown, F. (2006). Tourism and welfare: Ethics, responsibility, and sustainable well-being. Wallingford, Oxfordshire: CABI Publishing.

Kagan, F. (2013). Intercultural communication and socio-cultural mission of tourism: challenges and responses. Russia, Ivanovo: Tourism and hospitality beyond borders: tendencies and perspectives, $p$. 286.
Karmalskaya, E. (2013). Context and concept of ecological tourism market. Russia, Kazan: Ekologizacia, p. 142.

Kokorev, P. A. (2010). Implementation of the concept of corporate and social responsibility in tourism. Russia, Saint Petersburg: Izvestia of Saint Petersburg University of Economy and Finance, \#6.

Kuskov, A., \& Arseneva, E. (2006). Modern ecotourism: main concepts, trends and forms. Russia, Moscow: Tourlib.

Linstone, H. A., \& Turoff, M. (2011). Delphi: A brief look backward and forward. Technological Forecasting and Social Change, 78(9), 1712-1719.

Maksakova, L. (2005). Tourist - our most wanted guest. Russia: Mir Baikala, \#6.

Marshall, C., \& Rossman, G. B. (1999). Designing qualitative research. Thousand Oaks, California: Sage Publications.

Rigall-I-Torrent, R. (2008). Sustainable development in tourism municipalities: The role of public goods. Tourism Management, 29(5), 883-897.

Rio+20 (1997). What is sustainability? - Rio+20 the future we want. URL: http://www.un.org/en/sustainablefuture/sus tainability.shtml (Accessed on 17/09/2012)

Vespestad, M. K. (2010). Tour operators' insight into the Russian nature-based experience market. European Journal of Tourism Research, 3(1), 38-53.

Yin, R. K. (2003a). Applications of case study research (2nd ed.). Thousand Oaks: Sage Publications.

Yin, R. K. (2003b). Case study research: Design and methods (3rd ed.). Thousand Oaks, Calif.: Sage Publications.

Zeletdinova, E. A. (2005). Regional tourism: situation, problems, perspectives. Russia, Astrakhan: Social Research, 11, 96-105. 